\title{
運貨と輸配送量を内生化した都市内共同配送 モデルの構築と共同配送成立要因の基礎的分析
}

\author{
山田 忠史 ${ }^{1}$ ・福井 一涁 ${ }^{2}$ \\ 1正会員 京都大学大学院准教授 工学研究科都市社会工学専攻（ $=615-8540$ 京都市西京区京都大学桂） \\ E-mail: t.yamada@kiban.kuciv.kyoto-u.ac.jp \\ 2学生会員 京都大学大学院修士課程 工学研究科都市社会工学専攻 (同上) \\ E-mail: fukui.kazuaki@kiban.kuciv.kyoto-u.ac.jp
}

\begin{abstract}
都市内の貨物交通に起因する諸問題の解決・緩和に有用な都市内共同配送に着目し，輸配送ネットワー ク均衡モデルの枠組みで, 輸配送量, 運顀や共同配送運賃などを内生的に決定する共同配送モデルを提案 する．モデル化に際しては，実際に行われている共同配送の形態を基にして，荷主，消費者（消費市場）， 共同配送を委託する物流業者と受託する物流業者を対象に, それらの分権的な意思決定や行動の相互作用 を考慮して定式化する. 現実の数值との整合性を検討することにより, 提案したモデルの基本的性能を確 認するとともに，モデルを用いた基礎的な数值計算を行い，配送デポの施設費用や都市内の運行費用に注 目して，共同配送の成立要因について考察する.
\end{abstract}

Key Words : cooperative freight transport systems, network equilibrium, facility cost, operation cost

\section{1. はじめに}

近年，在庫の抑制，消費者ニーズの多様化やネット通 販の搪大が，多頻度小口配送を促進しており，都市内の 物流問題, 寸なわち, 配送車両の増加に伴う道路混雑の 悪化，環境負荷や交通事故のリスク増大などの一因とな っている. 一方, 物流業者にとっては, 多頻度小口配送 の増大により, 配送効率が悪化し, 配送費用の上昇に直 面している，それゆえ，異なる荷主や物流業者の貨物を 共同で配送すること（以下，共同配送と称する）の必要 性が, 国内外で以前から継続的に指摘されている ${ }^{1)-5}$. 実際に，これまでも，わが国をはじめとして，オランダ やイギリスなどにおいて，都市内共同配送の実施例が見 られるの。これらの事例や効果試算例のの多くから，共 同配送が，配送車両の台数削減や積載率向上，配送費用 削減や環境負荷抑制に効果的であることが示されている。 一方で, 必要な貨物量の確保や適切な運賃設定が難しく, 共同配送事業の採算性の確保も容易ではないために，共 同配送が実現に至らないことも示されてきた7,8.

都市内共同配送に関する既往研究は，事例紹介や数值 シミュレーションなど様々であるがの，共同配送システ ムをモデル化して，その成立要因を考究している研究は 少ない，谷口ら9や van Duin and Jagtman ${ }^{10}$ は，配送計画問 題を用いて，共同配送システムの $\mathrm{CO}_{2}$ 排出量の削減効果
や共同配送デポの配置について検討している．山田ら ${ }^{11)}$ は, 行政主導のエリア型共同集配送に注目し，共同配送 事業者の行動を明示的に考慮した配送計画問題を定式化 するとともに，そのモデルを用いて，エリア型共同配送 の成立条件や共同配送における行政の役割について分析

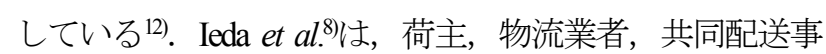
業者の行動を，利潤最大化を基にしてゲーム理論の枠組 みでモデル化し，数值計算により，共同配送運賃の設定 の難しさを示している.これらの既存研究においては, i) 最適な配送を算出する配送計画問題を基にしている場 合には，実際の行動とは乘離しており，ii) 配送量と運賃 は，相互に影響しながら内生的に決まるものであるが， それらが外生的に与えられているという問題を有寸る.

本研究では，輸配送量や運賃などを内生的に決定する 輸配送ネットワーク均衡モデルの枠組みで，それに都市 内の共同配送を組み込んだ「共同配送モデル」を提案す る. 共同配送運賃が内生化されることにより, 共同配送 の成立に直結する共同配送運賃への影響要因が解析的に 明らかになる．モデル化に際しては，京都市で大手物流 2社によって実際に行われている共同配送を参考にする. モデル化の対象となる主体は，荷主，消費者（消費市 場），物流業者である。これらの主体の分権的な意思決 定を反映し，行動の相互作用を考慮したうえで定式化を 行う. 構築したモデルは, 計算結果と現実の数值との整 
合性を検討することにより，その基本的性能を確認する とともに，モデルを用いた基礎的な数值計算を行い，配 送デポの施設費用や運行費用に注目して，共同配送の成 立要因について考察する.

\section{2. 共同配送モデル}

モデル化に際して，図-1のように，荷主，消費市場， 物流業者の行動に相互作用があると想定する. 本研究に おいて，消費市場とは，都市内の地区レベルの消費者の 集合体を想定する. 参考にした物流が宅配便であること から，商品の取引は荷主と消費者間であるが，その輸送 は，物流業者を介して行われるものとする，モデル内で 内生的に算定される数值は, 輸配送量, 販売価格, 購入 量, 共同配送委託量, 共同配送運賃である.

物流業者については2種類，すなわち，共同配送を行 う業者（以下，共同配送受託業者と称し，物流業者 $\bar{H}$ と表す）と，自社の配送量の一部もしくは全部を，共同 配送受託業者に委託料を支払って配送を委託する物流業 者（以下，共同配送委託業者と称し，物流業者 $H$ と表 す）である. 京都市で実際に行われている共同配送に倣 って, 輸配送経路を図-2のように設定する. 物流業者は 市外に存在するI個の荷主から市郊外の中継ターミナル

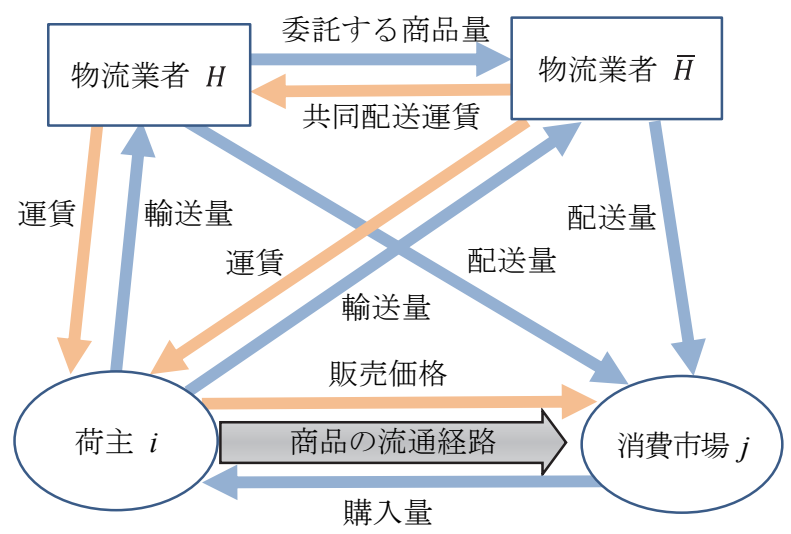

図-1 モデル化される主体間の関係

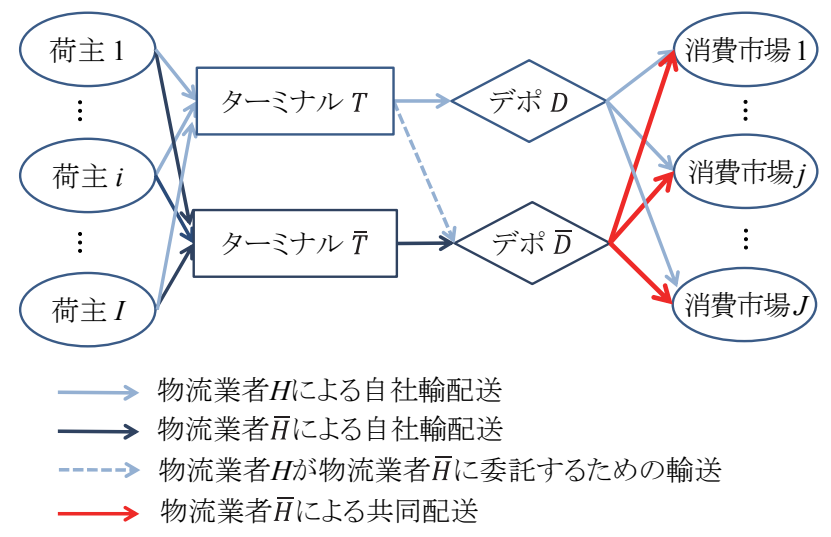

図-2 モデル化の対象とする輸配送ネットワーク
（以下，ターミナルと略称する）まで商品を輸送し, さ らに, ターミナルから市内の配送デポ（以下，デポと略 称する）まで輸送して，デポから市内のJ個の消費市場 まで配送する，共同配送委託業者はターミナル $T$ とデポ $D$ を運営し, 共同配送受託業者はターミナル $\bar{T}$ とデポ $\bar{D}$ を運営する。配送経路は3種類，すなわち，i)共同配 送委託業者が荷主から消費市場まで自社輸配送する経路, ii)共同配送受託業者が荷主から消費市場まで自社輸配送 する経路， iii)共同配送委託業者がデポ $\bar{D}$ まて輸送した 後, デポ $\bar{D}$ 以降を共同配送受託業者が自社貨物ととも に共同配送する経路である，共同配送委託業者が共同配 送受託業者に配送を委託する際には，共同配送運顀を受 託業者に支払うものとする.

以下に，対象とする各主体の行動を定式化する. なお， 式中の゙は均衡解を表す.

\section{（1）荷主の行動}

荷主は，消費者（消費市場）に商品を販売し，その 輸配送を物流業者に依頼する。荷主 $i$ の行動は, 利潤 $P_{i}(\bullet)$ の最大化を目的として, 以下のように表される.

$$
\begin{aligned}
& \operatorname{Max}_{Q_{T D}^{H}, Q_{T \bar{H}}^{\bar{H}}, Q_{I \bar{D}}^{H}} P_{i}\left(Q_{T D}^{H}, Q_{\overline{T D}}^{\bar{H}}, Q_{T \bar{D}}^{H}\right)=\sum_{j=1}^{J} \rho_{i j}^{*}\left(q_{i T D j}^{H}+q_{i \overline{T D} j}^{\bar{H}}+q_{i T \bar{D} j}^{H}\right) \\
& -f_{i}\left(Q_{T D}^{H}, Q_{\overline{T D}}^{\bar{H}}, Q_{T \bar{D}}^{H}\right)-\sum_{j=1}^{J} \beta_{i j}^{*}\left(q_{i T D j}^{H}+q_{i \bar{T} \overline{\bar{H}} j}^{\overline{\bar{H}}}+q_{i \overline{\mathrm{D}} j}^{H}\right) \\
& \text { subject to } q_{i T D j}^{H} \geq 0 \forall j, q_{i T \bar{H} j}^{\bar{H}} \geq 0 \forall j, q_{i T \bar{D} j}^{H} \geq 0 \forall j
\end{aligned}
$$

ここに,

$q_{i T D j}^{H} \quad$ : ターミナル $T$ とデポ $D$ を経由して $i j$ 間の商 品を運ぶ，物流業者 $H$ の自社輸配送量（重 量)

$q_{i \bar{T} D j}^{\bar{H}} \quad:$ ターミナル $\bar{T}$ とデポ $\bar{D}$ を経由して $i j$ 間の商 品を運ぶ，物流業者 $\bar{H}$ の自社輸配送量（重 量)

$q_{i \bar{D} j}^{H} \quad$ : 物流業者 $H$ がターミナル $T$ を経由して $i \bar{D}$ 間を 輸送し，物流業者 $\bar{H}$ が $\bar{D} j$ 間を配送する商 品の量 (重量)

$Q_{T D}^{H} \quad: q_{i T D j}^{H}$ を要素とするIJ次元ベクトル

$Q_{\overline{T D}}^{\bar{H}} \quad: q_{i \bar{T} D j}^{\bar{H}}$ を要素とするIJ次元ベクトル

$Q_{T \bar{D}}^{H} \quad: q_{i T \bar{D} j}^{H}$ を要素とする $I J$ 次元ベクトル

$\rho_{i j} \quad:$ 荷主 $i$ から消費市場 $j$ への商品の販売価格

$f_{i}(\bullet) \quad$ : 生産, 保管, 取引, 施設に要する荷主 $i$ の 費用関数

$\beta_{i j} \quad$ : 荷主が物流業者に支払う運賃

$q_{i \bar{T} D j}^{\bar{H}}$ は，物流業者 $H$ が $\bar{H}$ に配送を委託する商品量に 相当するので，共同配送委託量を表す．輸配送される商 品の運貨は, 荷主から物流業者 $H$ に支払われるので, $q_{i T \bar{D} j}^{H}$ の添字はHのみで表記する.

費用関数 $f_{i}(\bullet)$ が連続かつ凸であり, すべての荷主の最 
適性条件が同時に成り立つ場合，この問題は以下の変分 不等式を満たす $\left(Q_{T D}^{H}, Q_{\bar{T}}^{\bar{H}}, Q_{T \bar{D}}^{H}\right)$ を求める問題と等価であ る.

$$
\begin{aligned}
& \sum_{j=1}^{J} \sum_{i=1}^{I}\left[\frac{\partial f_{i}\left(Q_{T D}^{H^{*}}, Q_{T \bar{D}}^{H^{*}}, Q_{T \bar{T}}^{\bar{H}^{*}}\right)}{\partial q_{i T D j}^{H}}+\beta_{i j}^{*}-\rho_{i j}^{*}\right] \times\left[q_{i T D j}^{H}-q_{i T D j}^{H^{*}}\right] \\
& +\sum_{j=1}^{J} \sum_{i=1}^{I}\left[\frac{\partial f_{i}\left(Q_{T D}^{H^{*}}, Q_{\bar{D}}^{H^{*}}, Q_{\overline{T D}}^{\bar{H}^{*}}\right)}{\partial q_{i \bar{T} \bar{D} j}^{\bar{H}}}+\beta_{i j}^{*}-\rho_{i j}^{*}\right] \times\left[q_{i \overline{\bar{H}} \overline{\bar{H}} j}^{\overline{\bar{H}}}-q_{i \overline{\bar{H}^{*}} j}\right] \\
& +\sum_{j=1}^{J} \sum_{i=1}^{I}\left[\frac{\partial f_{i}\left(Q_{T D}^{H^{*}}, Q_{T \bar{H}}^{H^{*}}, Q_{\bar{T} \bar{H}^{*}}\right)}{\partial q_{i T \bar{D} j}^{H}}+\beta_{i j}^{*}-\rho_{i j}^{*}\right] \times\left[q_{i T \bar{D} j}^{H}-q_{i T \bar{D}_{j}}^{H^{*}}\right] \geq 0 \\
& \forall\left(Q_{T D}^{H}, Q_{T \bar{D}}^{H}, Q_{\bar{T} \bar{D}}^{\bar{H}}\right) \in R_{+}^{I J+I J+I J}
\end{aligned}
$$

\section{（2）共同配送委託業者の行動}

共同配送委託業者，すなわち，物流業者 $H$ の行動は， 利潤 $P_{H}(\bullet)$ の最大化を目的として，以下のように定式化 できる

$$
\begin{aligned}
& \operatorname{Max}_{Q_{T D}^{H}, Q_{\bar{D}}^{H}} P_{H}\left(Q_{T D}^{H}, Q_{T \bar{D}}^{H}\right)=\sum_{i=1}^{I} \sum_{j=1}^{J} \beta_{i j}^{*}\left(q_{i T D j}^{H}+q_{i \bar{T} j}^{H}\right) \\
& -\alpha_{H \bar{H}}^{*} \sum_{i=1}^{I} \sum_{j=1}^{J} q_{i \bar{D} j}^{H}-\sum_{i=1}^{I} C_{i T}^{H}\left(Q_{T D}^{H}, Q_{T \bar{D}}^{H}\right)-C_{T D}^{H}\left(Q_{T D}^{H}\right) \\
& -C_{T \bar{D}}^{H}\left(Q_{T \bar{D}}^{H}\right)-\sum_{j=1}^{J} C_{D j}^{H}\left(Q_{T D}^{H}\right)-g_{H}\left(Q_{T D}^{H}\right)-c_{H}\left(Q_{T D}^{H}, Q_{T \bar{D}}^{H}\right) \\
& \text { subject to } q_{i T D j}^{H} \geq 0 \forall i, \forall j, q_{i T \bar{D} j}^{H} \geq 0 \quad \forall i, \forall j
\end{aligned}
$$
ここに

$\alpha_{H \bar{H}}:$ 物流業者 $H$ から物流業者 $\bar{H}$ に対して支払わ れる共同配送運賃

$C_{i T}^{H}(\bullet): i T$ 間における物流業者 $H$ の運行費用

$C_{T D}^{H}(\bullet): T D$ 間における物流業者 $H$ の運行費用

$C_{T \bar{D}}^{H}(\bullet): T \bar{D}$ 間における物流業者 $H$ の運行費用

$C_{D j}^{H}(\bullet) \quad: D j$ 間における物流業者 $H$ の運行費用

$g_{H}(\bullet) \quad$ : 物流業者Hのデポの施設費用

$c_{H}(\bullet) \quad$ : 物流業者Hのターミナルの施設費用

施設費用は，施設の整備や維持管理などに要する費用

である．運行費用は，貨物車の運行に要する費用であり， 貨物車の固定費用も含まれる.

施設費用関数と運行費用関数が連続かつ凸であれば, この問題は, $\left(Q_{T D}^{H}, Q_{T \bar{D}}^{H}\right)$ を求める以下の変分不等式問題 と等価である.

$$
\begin{aligned}
& \sum_{j=1}^{J} \sum_{i=1}^{I}\left[\frac{\partial C_{i T}^{H}\left(Q_{T D}^{H^{*}}, Q_{T \bar{D}}^{H^{*}}\right)}{\partial q_{i T D j}^{H}}+\frac{\partial C_{T D}^{H}\left(Q_{T D}^{H^{*}}\right)}{\partial q_{i T D j}^{H}}+\frac{\partial C_{D j}^{H}\left(Q_{T D}^{H^{*}}\right)}{\partial q_{i T D j}^{H}}\right. \\
& \left.+\frac{\partial g_{H}\left(Q_{D}^{H^{*}}\right)}{\partial q_{i T D j}^{H}}+\frac{\partial c_{H}\left(Q_{T D}^{H^{*}}, Q_{T \bar{D}}^{H^{*}}\right)}{\partial q_{i T D j}^{H}}-\beta_{i j}^{*}\right] \times\left[q_{i T D j}^{H}-q_{i T D j}^{H^{*}}\right] \\
& +\sum_{j=1}^{J} \sum_{i=1}^{I}\left[\alpha_{H \bar{H}}^{*}+\frac{\partial C_{i T}^{H}\left(Q_{T D}^{H^{*}}, Q_{T \bar{D}}^{H^{*}}\right)}{\partial q_{i \overline{\bar{D}} j}^{H}}+\frac{\partial C_{T \overline{\bar{D}}}^{H}\left(Q_{\bar{T}}^{H_{\bar{D}}^{*}}\right)}{\partial q_{i T \bar{D} j}^{H}}\right. \\
& \left.+\frac{\partial c_{H}\left(Q_{T D}^{H^{*}}, Q_{T \bar{D}}^{H^{*}}\right)}{\partial q_{i \bar{D} \bar{j} j}^{H}}-\beta_{i j}^{*}\right] \times\left[q_{i \bar{D} \bar{D} j}^{H}-q_{i \bar{D} \bar{D} j}^{H^{*}}\right] \geq 0 \forall\left(Q_{T D}^{H}, Q_{T \bar{D}}^{H}\right) \in R_{+}^{I J+I J}
\end{aligned}
$$

\section{（3）共同配送受託業者の行動}

共同配送受託業者（物流業者 $\bar{H}$ ) の行動は，利潤 $P_{\bar{H}}(\bullet)$ の最大化を目的として, 以下のように表される.

$$
\begin{aligned}
& \operatorname{Max}_{Q_{T \bar{H}}^{H}, Q_{T \bar{H}}^{H}} P_{\bar{H}}\left(Q_{\overline{T D}}^{\overline{\bar{H}}}, Q_{T \bar{D}}^{H}\right)=\sum_{i=1}^{I} \sum_{j=1}^{J} \beta_{i j}^{*} q_{i \bar{T} \overline{\bar{H}}}^{\overline{\bar{H}}} \\
& +\alpha_{H \bar{H}}^{*} \sum_{j=1}^{J} \sum_{i=1}^{I} q_{i \bar{D} \bar{j}}^{H}-\sum_{i=1}^{I} C_{i \bar{T}}^{\bar{H}}\left(Q_{\bar{T}}^{\bar{H}}\right)-C_{\overline{T D}}^{\bar{H}}\left(Q_{\overline{T D}}^{\bar{H}}\right) \\
& -\sum_{j=1}^{J} C_{\bar{D} j}^{\bar{H}}\left(Q_{\overline{T D}}^{\bar{H}}, Q_{T \bar{D}}^{H}\right)-g_{\bar{H}}\left(Q_{\overline{T D}}^{\bar{H}}, Q_{T \bar{D}}^{H}\right)-c_{\bar{H}}\left(Q_{\overline{T D}}^{\bar{H}}\right)
\end{aligned}
$$

subject to $q_{i \bar{T} \bar{H} j}^{\bar{H}} \geq 0 \forall i, \forall j, q_{i T \bar{D} j}^{H} \geq 0 \forall i, \forall j$

$C_{i \bar{T}}^{\bar{H}}(\bullet) \quad: i \bar{T}$ 間における物流業者 $\bar{H}$ の運行費用

$C_{\bar{T}}^{\bar{H}}(\bullet): \overline{T D}$ 間における物流業者 $\bar{H}$ の運行費用

$C_{\bar{D} j}^{\bar{H}}(\bullet): \bar{D} j$ 間における物流業者 $\bar{H}$ の運行費用

$g_{\bar{H}}(\bullet) \quad$ : 物流業者 $\bar{H}$ のデポの施設費用

$c_{\bar{H}}(\bullet) \quad$ : 物流業者 $\bar{H}$ のターミナルの施設費用

施設費用関数と運行費用関数が連続かつ凸であれば, この問題は以下の不等式を満たす $\left(Q_{\overline{T D}}^{\bar{H}}, Q_{\bar{D}}^{H}\right)$ を求める問 題と等価である.

$$
\begin{aligned}
& \sum_{j=1}^{J} \sum_{i=1}^{I}\left[\frac{\partial C_{i \overline{\bar{T}}}^{\bar{H}}\left(Q_{\bar{T} \overline{\bar{T}^{*}}}\right)}{\partial q_{i \overline{\bar{T}} j}^{\bar{H}}}+\frac{\partial C_{\bar{T}}^{\overline{\bar{T}}}\left(Q_{\bar{T} \overline{\bar{T}^{*}}}\right)}{\partial q_{i \overline{\bar{T}} j}^{\bar{T}}}\right.
\end{aligned}
$$

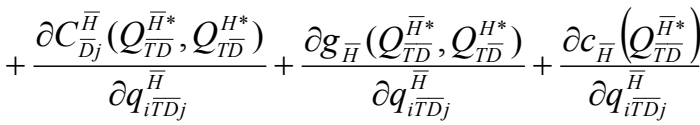

$$
\begin{aligned}
& \left.-\beta_{i j}^{*}\right] \times\left[q_{i \bar{T} \overline{\bar{H}} j}^{\bar{H}}-q_{i \bar{T} \overline{T^{*}} j}\right] \\
& +\sum_{j=1}^{J} \sum_{i=1}^{I}\left[\frac{\partial C_{\bar{D} j}^{\bar{H}}\left(Q_{\bar{T}}^{\bar{T}^{*}}, Q_{T \bar{D}}^{H^{*}}\right)}{\partial q_{i T \bar{D} j}^{H}}+\frac{\partial g_{\bar{H}}\left(Q_{\bar{H}}^{\bar{H}^{*}}, Q_{T \bar{D}}^{H^{*}}\right)}{\partial q_{i T \bar{D} j}^{H}}\right. \\
& \left.-\alpha_{H \bar{H}}^{*}\right] \times\left[q_{i T \bar{D} j}^{H}-q_{i T \bar{D} j}^{H^{*}}\right] \geq 0 \quad \forall\left(Q_{\bar{T} \overline{\bar{H}}}^{\bar{H}}, Q_{T \bar{D}}^{H}\right) \in R_{+}^{I J+I J}
\end{aligned}
$$

\section{（4）消費市場の均衡条件}

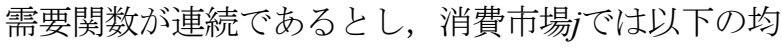
衡条件（相補性条件）が成立すると仮定する.

$$
d_{j}\left(\rho^{*}\right) \begin{cases}=\sum_{i=1}^{I} q_{i T D j}^{H^{*}}+\sum_{i=1}^{I} q_{i \overline{H^{*}} j}+\sum_{i=1}^{I} q_{i T \bar{D} j}^{H^{*}} & \text { if } \rho_{i j}^{*}>0 \\ \leq \sum_{i=1}^{I} q_{i T D j}^{H^{*}}+\sum_{i=1}^{I} q_{i \bar{T} \overline{T^{*}} j}+\sum_{i=1}^{I} q_{i T \bar{D} j}^{H^{*}} & \text { if } \rho_{i j}^{*}=0\end{cases}
$$

$$
\text { ここに, }
$$

$\rho \quad: \rho_{i j}$ を要素とする $I J$ 次元ベクトル

$d_{j}\left(\rho^{*}\right) \quad$ : 消費市場 $j$ での需要関数

均衡状態において, 式(10)は，すべての消費市場につ いて同時に満たされる必要があり, そのことは以下の変 分不等式で記述できる.

$$
\begin{array}{r}
\sum_{j=1}^{J} \sum_{i=1}^{I}\left[\left(q_{i T D j}^{H^{*}}+q_{i \bar{T} \overline{H^{*}} j}^{\bar{H}^{*}}+q_{i T \bar{D} j}^{H^{*}}\right)-d_{j}\left(\rho^{*}\right)\right] \times\left[\rho_{i j}-\rho_{i j}^{*}\right] \geq 0 \\
\forall \rho \in R_{+}^{I J}
\end{array}
$$




\section{（5）輸配送ネットワーク全体の均衡条件}

均衡状態においては, 荷主や物流業者の最適性条件, および，消費市場の均衡条件が同時に満たされる．変分 不等式における和と各成分との関係を考慮すれば，対象 とする輸配送ネットワーク全体の均衡条件は，式 (3),(6),(9),(11)の左辺の和をとり，それが非負となるよう な $\left(Q_{T D}^{H^{*}}, Q_{\overline{T D}}^{\bar{H}^{*}}, Q_{T \bar{D}}^{H^{*}}, \rho^{*}\right) \in R_{+}^{I J+I J+I J+I J}$ を求めることと数理的 に等価であるので 13)15), 以下のように表される.

$\sum_{j=1}^{J} \sum_{i=1}^{I}\left[\frac{\partial f_{i}\left(Q_{T D}^{H^{*}}, Q_{\bar{H}}^{\bar{H}^{*}}, Q_{T \bar{D}}^{H^{*}}\right)}{\partial q_{i T D j}^{H}}+\frac{\partial C_{i T}^{H}\left(Q_{T D}^{H^{*}}, Q_{T \bar{D}}^{H^{*}}\right)}{\partial q_{i T D j}^{H}}\right.$

$+\frac{\partial C_{T D}^{H}\left(Q_{T D}^{H^{*}}\right)}{\partial q_{i T D j}^{H}}+\frac{\partial C_{D j}^{H}\left(Q_{T D}^{H^{*}}\right)}{\partial q_{i T D j}^{H}}+\frac{\partial g_{H}\left(Q_{T D}^{H^{*}}\right)}{\partial q_{i T D j}^{H}}$

$\left.+\frac{\partial c_{H}\left(Q_{T D}^{H^{*}}, Q_{T \bar{D}}^{H^{*}}\right)}{\partial q_{i T D j}^{H}}-\rho_{i j}^{*}\right] \times\left[q_{i T D j}^{H}-q_{i T D j}^{H^{*}}\right]$

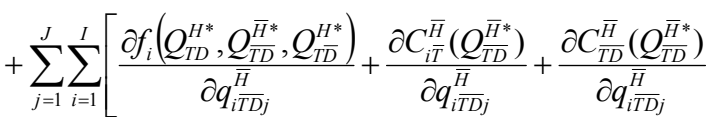

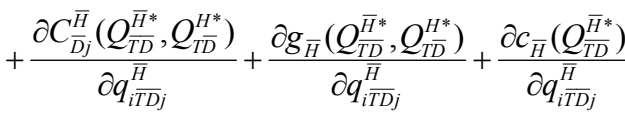

$\left.-\rho_{i j}^{*}\right] \times\left[q_{i \bar{T} \bar{H} j}^{\bar{H}}-q_{i \bar{T} \overline{H^{*}} j}\right]+\sum_{j=1}^{J} \sum_{i=1}^{I}\left[\frac{\partial f_{i}\left(Q_{T D}^{H^{*}}, Q_{\overline{H^{*}}}^{\bar{H}^{*}}, Q_{T \bar{D}}^{H^{*}}\right)}{\partial q_{i \bar{T} \bar{D} j}^{H}}\right.$

$+\frac{\partial C_{i T}^{H}\left(Q_{T T^{*}}^{H^{*}}, Q_{T \bar{D}}^{H^{*}}\right)}{\partial q_{i T \bar{D} j}^{H}}+\frac{\partial C_{T \bar{D}}^{H}\left(Q_{\bar{D}}^{H^{*}}\right)}{\partial q_{i T \bar{D} j}^{H}}+\frac{\partial C_{\bar{D} j}^{\bar{H}}\left(Q_{\overline{D_{\bar{D}}^{*}}}^{\bar{H}^{*}}, Q_{T \bar{D}}^{H^{*}}\right)}{\partial q_{i \bar{D} \bar{D} j}^{H}}$

$\left.+\frac{\partial g_{\bar{H}}\left(Q_{\overline{H^{*}}}^{\bar{H}^{*}}, Q_{T \bar{D}}^{H^{*}}\right)}{\partial q_{i T \bar{D} j}^{H}}+\frac{\partial c_{H}\left(Q_{D D^{*}}^{H^{*}}, Q_{T \bar{D}}^{H^{*}}\right)}{\partial q_{i \bar{T} \bar{D} j}^{H}}-\rho_{i j}^{*}\right] \times\left[q_{i \bar{D} \bar{D} j}^{H}-q_{i \overline{D^{*}} j}^{H^{*}}\right]$

$+\sum_{j=1}^{J} \sum_{i=1}^{I}\left[\left(q_{i T D j}^{H^{*}}+q_{i \bar{H}^{*} j}^{\bar{H}^{*}}+q_{i T \bar{D}_{j}}^{H^{*}}\right)-d_{j}\left(\rho^{*}\right)\right] \times\left[\rho_{i j}-\rho_{i j}^{*}\right] \geq 0$

$$
\forall\left(Q_{T D}^{H^{*}}, Q_{\overline{T D}}^{\overline{\bar{H}}^{*}}, Q_{T \bar{D}}^{H^{*}}, \rho^{*}\right) \in R_{+}^{I J+I J+I J+I J}
$$

式(12)の解の存在については, 既存のネットワーク均 衡モデル ${ }^{13)-15)}$ と同様に証明できる. $f_{i}(\bullet), C_{i T}^{H}(\bullet), C_{i \bar{T}}^{\bar{H}}(\bullet)$, $C_{T D}^{H}(\bullet), C_{\bar{T} D}^{\bar{H}}(\bullet), C_{T \bar{D}}^{H}(\bullet), C_{D j}^{H}(\bullet), C_{\bar{D} j}^{\bar{H}}(\bullet), g_{H}(\bullet), g_{\bar{H}}(\bullet), c_{H}(\bullet)$, $c_{\bar{H}}(\bullet)$ が凸関数, $d_{j}(\bullet)$ が単調減少関数で, これらの凸 関数族の中に一つでも狭義凸関数族が含まれ， $d_{j}(\bullet)$ が 狭義単調であれば，解の一意性を保証 13),15,16)できる，式

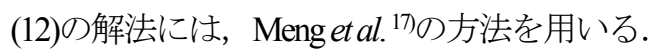

\section{(6) 運賃の導出}

運賃については，式(3)より， $q_{i T D j}^{H}>0$ のとき，

$$
\beta_{i j}^{*}=\rho_{i j}^{*}-\frac{\partial f_{i}\left(Q_{T D}^{H^{*}}, Q_{T \bar{D}}^{H^{*}}, Q_{\overline{T D}}^{\bar{H}^{*}}\right)}{\partial q_{i T D j}^{H}}
$$

と導出される。また，共同配送運賃については，式(9) より, $q_{i T \bar{D} j}^{H}>0$ のとき,

$$
\alpha_{H \bar{H}}^{*}=\frac{\partial C_{\bar{D} j}^{\overline{\bar{H}}}\left(Q_{\bar{T} \overline{\bar{D}}}^{\bar{H}^{*}}, Q_{T \bar{D}}^{H^{*}}\right)}{\partial q_{i \overline{\bar{D}} j}^{H}}+\frac{\partial g_{\bar{H}}\left(Q_{\bar{H}}^{\bar{H}^{*}}, Q_{T \bar{D}}^{H^{*}}\right)}{\partial q_{i T \bar{D} j}^{H}}
$$

と導出される.

\section{3. 数值計算}

\section{(1) 初期設定}

構築したモデルを用いて，数值計算を行う. 簡単のた めに, 荷主と消費市場の数は2 とする. 京都市の事例に 倣い，共同配送委託業者は受託業者と比べて，市内での 事業規模が小さいものとして，デポの施設費用関数や運 行費用関数の係数值に差を設ける. 各関数の関数形と係 数值は以下の通りである.

$$
\begin{aligned}
& f_{i}=0.026\left(\sum_{j=1}^{2}\left(q_{i T D j}^{H}+q_{i \bar{T} \overline{\bar{H}} j}^{\bar{H}}+q_{i T \bar{D} j}^{H}\right)\right)^{2} \\
& +165 \sum_{j=1}^{2}\left(q_{i T D j}^{H}+q_{i \bar{T} j}^{\overline{\bar{H}}}+q_{i \bar{D} \bar{D}}^{H}\right) \\
& g_{H}=8.0 \sum_{j=1}^{2} \sum_{i=1}^{2} q_{i T D j}^{H} \\
& g_{\bar{H}}=3.2 \sum_{j=1}^{2} \sum_{i=1}^{2}\left(q_{i \bar{D} j}^{\overline{\bar{H}}}+q_{i \bar{T} \bar{j}}^{H}\right) \\
& c_{H}=1.0 \sum_{j=1}^{2} \sum_{i=1}^{2}\left(q_{i T D j}^{H}+q_{i T \bar{D} j}^{H}\right) \\
& c_{\bar{H}}=1.0 \sum_{j=1}^{2} \sum_{i=1}^{2} q_{i \bar{T} D_{j}}^{\overline{\bar{H}}} \\
& C_{i T}^{H}=0.003\left(\sum_{j=1}^{2} \sum_{i=1}^{2}\left(q_{i T D j}^{H}+q_{i T \bar{D} j}^{H}\right)\right)^{2}+0.8 \sum_{j=1}^{2} \sum_{i=1}^{2}\left(q_{i T D j}^{H}+q_{i T \bar{D} j}^{H}\right) \\
& C_{T D}^{H}=0.0045\left(\sum_{j=1}^{2} \sum_{i=1}^{2} q_{i T D j}^{H}\right)^{2}+0.4 \sum_{j=1}^{2} \sum_{i=1}^{2} q_{i T D j}^{H} \\
& C_{D j}^{H}=0.015\left(\sum_{j=1}^{2} \sum_{i=1}^{2} q_{i T D j}^{H}\right)^{2}+2.8 \sum_{j=1}^{2} \sum_{i=1}^{2} q_{i T D j}^{H} \\
& C_{i \bar{T}}^{\bar{H}}=0.001\left(\sum_{j=1}^{2} \sum_{i=1}^{2} q_{i \bar{H} \overline{\bar{H}} j}\right)^{2}+0.32 \sum_{j=1}^{2} \sum_{i=1}^{2} q_{i \bar{T} D j}^{\bar{H}} \\
& C_{\overline{T D}}^{\bar{H}}=0.0015\left(\sum_{j=1}^{2} \sum_{i=1}^{2} q_{i \bar{T} D j}\right)^{2}+0.16 \sum_{j=1}^{2} \sum_{i=1}^{2} q_{i \bar{D} \bar{T} j}^{\bar{H}} \\
& C_{T \bar{D}}^{H}=0.0045\left(\sum_{j=1}^{2} \sum_{i=1}^{2} q_{i T \bar{D} j}^{H}\right)^{2}+0.4 \sum_{j=1}^{2} \sum_{i=1}^{2} q_{i T \bar{T} j}^{H} \\
& C_{\bar{D} j}^{\bar{H}}=0.005\left(\sum_{j=1}^{2} \sum_{i=1}^{2}\left(q_{i \overline{D j} j}^{\overline{\bar{H}}}+q_{i \overline{D_{j}} j}^{H}\right)\right)^{2}+1.12 \sum_{j=1}^{2} \sum_{i=1}^{2}\left(q_{i \bar{T} \overline{\bar{T}} j}^{\overline{\bar{T}}}+q_{i T \bar{D} j}^{H}\right) \\
& d_{j}=1200-3.0 \sum_{i=1}^{2} \rho_{i j}
\end{aligned}
$$

上述の関数形と係数值については，問題設定を少しで も現実の輸配送に近づけるために，共同配送運賃と配送 量に関して，実際の值と整合するように調整した．ただ し，物流業者の運行費用関数の関数形については，既存 研究18)を参考にして設定した. 第1項は, ターミナルや デポ周辺での交通混雑に伴う費用を表し，都市内ほど混 雑の影響が大きくなるように，係数值を設定した．第2 項は，輸送手段の運行に要する費用を表し，係数值につ いては，実際のデータ19) を参考にして，距離に応じて 
設定した. また，荷主の費用関数の関数形についても， 既存研究20)を基にして設定しており，輸配送量の増大に 伴う倉庫などでの混雑を考慮して，第1項を非線形と仮 定している.

調整の結果，実際に共同配送を行っている京都市の物 流業者へのヒアリング調査結果から，通常の配送運賃は 共同配送運賃の 1.3 倍であり，一方，モデルを用いた計 算結果では1.9倍となった。また，配送量について，実 際の宅配取扱個数データ21)を参照し，京都市で実際に共 同配送を受託している業者を勘案すれば，受託業者が委 託業者の4〜10倍であり，計算結果では4.2倍（以下に示 す推定值に基づいて，464.6\%(105.2+4.2)より）となった. これらの結果により，現実との整合性が十分に確保され たわけではないが，少しでも整合を図ることが，モデル の性能の妥当性確保や，以降の計算ケースの結果を解釈 するうえで有効になるものと考えられる.

配送量と共同配送運貨の推定值は以下のようになった （以降，この結果を基本ケースと称する）.

$$
q_{i T D j}^{H}=4.2, \quad q_{i \bar{T} \bar{j} j}^{\bar{H}}=464.6, \quad q_{i T \bar{D} j}^{H}=105.2, \quad \alpha_{H \bar{H}}=7.3
$$

式(14)から，共同配送運賃は，共同配送受託業者のデ ポの限界施設費用と, 共同配送受託業者のデポから消費 市場までの限界運行費用に影響を受けることが見て取れ る.したがって，以降では，これらの施設費用や運行費 用を変化させて数值計算を行うことにより，共同配送の 成立要因について基礎的考察を行う.

\section{（2）デポの施設費用の影響}

デポの施設費用関数において，共同配送委託業者と受 託業者の間に差がない場合について計算する，すなわち， デポの費用に業者の規模が反映されない場合である。具 体的には，基本ケースと比較して，式 (16)と(17)を，以 下のように変更する.

$$
\begin{gathered}
g_{H}=5.6 \sum_{j=1}^{2} \sum_{i=1}^{2} q_{i T D j}^{H} \\
g_{\bar{H}}=5.6 \sum_{j=1}^{2} \sum_{i=1}^{2}\left(q_{i \bar{T} \bar{H} j}+q_{i T \bar{D} j}^{H}\right)
\end{gathered}
$$

基本ケースと比較して，単位配送量あたりのデポの施 設費用が，共同配送委託業者では小さくなり，受託業者 では大きくなる．デポの施設費用以外の設定は，基本ケ 一スと同様とする.このとき，配送量と共同配送運賃は， 次のようになった。

$$
q_{i T D j}^{H}=92.4, \quad q_{i \overline{T D} j}^{\bar{H}}=422.4, \quad q_{i T \bar{D} j}^{H}=55.8, \quad \alpha_{H \bar{H}}=9.5
$$

共同配送委託業者の自社配送量が増大し，共同配送へ の委託量が減少するとともに，共同配送運顀が上昇して いる．この結果から，共同配送受託業者のデポの施設費 用は，委託業者よりも低廉であることが，共同配送の成 立において有効であると考えられる.

\section{（3）運行費用の影響}

つぎに，デポから消費市場までの運行費用関数につい て，共同配送委託業者と受託業者の間に差がない場合に ついて計算する. すなわち，この区間の業者の規模が反 映されない場合である.このとき，基本ケースと比較し て，式(22)と(26)が，以下のように変更される.

$$
\begin{gathered}
C_{D j}^{H}=0.01\left(\sum_{j=1}^{2} \sum_{i=1}^{2} q_{i \overline{T D} j}^{\bar{H}}\right)^{2}+1.96 \sum_{j=1}^{2} \sum_{i=1}^{2} q_{i \bar{T} \bar{J} j}^{\bar{H}} \\
C_{\bar{D} j}^{\bar{H}}=0.01\left(\sum_{j=1}^{2} \sum_{i=1}^{2}\left(q_{i \bar{T} \bar{H} j}^{\bar{H}}+q_{i T \bar{D} j}^{H}\right)\right)^{2}+1.96 \sum_{j=1}^{2} \sum_{i=1}^{2}\left(q_{i \bar{T} \bar{H} j}^{\bar{H}}+q_{i T \bar{D} j}^{H}\right)
\end{gathered}
$$

基本ケースと比較して，配送量による運行費用への影 響が，共同配送委託業者では小さくなり，受託業者では 大きくなる. これら以外の設定は，基本ケースと同様で ある. このとき, 配送量と共同配送運賃は，以下のよう になった.

$$
q_{i T D j}^{H}=138.2, q_{i \bar{T} \bar{H} j}^{\bar{H}}=397.8, q_{i T \bar{D} j}^{H}=29.3, \alpha_{H \bar{H}}=12.1
$$

このケースについても, 共同配送委託業者の自社配送 量の増大，共同配送への委託量の減少，および，共同配 送運賃の上昇が見られる.この結果は，共同配送受託業 者の都市内の運行費用は, 委託業者よりも低廉であるこ とが，共同配送の成立において有効であることを示唆し ている.

\section{4. おわりに}

本研究では，都市内の配送車両の走行抑制方策として 有用とされる都市内共同配送に注目し，その成立要因を 考究するために，輸配送量や運覒を内生的に決定する輸 配送ネットワーク均衡モデル，すなわち，共同配送モデ ルを構築した。モデル化に際しては，実際に行われてい る共同配送の事例を基にして，流通や輸配送の経路を設 定するとともに，現実との值と計算結果を比較すること により，モデルの性能の妥当性について確認した.

モデルを用いた基礎的な数值計算の結果，共同配送受 託業者の方が委託業者よりも，デポの施設費用が低廉で あること，および，都市内の運行費用が抑制されること が，共同配送の成立に有効である可能性が示された．前 者については，デポ内での機械化や省力化，ならびに， 廃校跡などの公共用地を利用したデポ用地の低廉な提供 などが一助となるものと考えられる．また，後者につい ては，都市内で適用可能な車両の大型化，例えば，2卜 ン未満の車両から2トン車への大型化や，配送経路の最 適化，および，駐停車場所の優遇措置や流入規制地区一 の流入許可などが有用であると考えられる.

本論文は，都市内共同配送の一形態においてモデル化 を行い, 基礎的な数值計算から, その成立要因を考察し たに過ぎない. 本研究で提案したモデルには，さらなる 
モデルの妥当性検証，および，係数值の広範な変化に基 ら゙く多様なケーススタディによる成立要因分析という課 題が残されている. サプライチェーン全般の挙動メカニ ズムを包含することなどにより，より精緻に要因分析を 行うことも今後の課題である. また, 本研究が取り上げ た形態以外にも，共同配送には多様な形態が存在する.

例えば，共同配送を専業とする事業者が存在するケース などであり，モデル化においては，行動を記述すべき主 体の増加が予想される. 今後はそれらの形態についても モデル化を試みる必要がある。

謝辞 : 本研究の一部はJSPS科研費15K06251の助成を受け たものである.

\section{参考文献}

1) 松本昌二, 高橋洋二: 土木計画学における物流問題と 物流研究の課題, 土木計画学研究・講演集, Vol. 14 (2), pp. 141-147, 1991.

2) 高田邦道 : 共同化推進のための公共施設整備, 土木計 画学研究・講演集, No. 15 (2), pp. 17-18, 1992.

3) Taniguchi, E., Thompson, R. G., Yamada, T. and van Duin, J. H. R.: City Logistics - Network Modelling and Intelligent Transport Systems, Pergamon, 2001.

4) 苦瀬博仁, 高田邦道, 高橋洋二 : 都市の物流マネジメ ント, 勁草書房, 2006.

5) 寺前悠, 澤野宏 : 総合物流施策大綱（2013-2017）の推 進に向けて, 交通工学, Vol. 49, No. 2, pp. 8-12, 2014.

6) Yamada, T.: Cooperative freight transport systems, In: City Logistics: Mapping The Future (Taniguchi, E. and Thompson, R. G. Eds.), pp. 167-176, CRC Press, 2014.

7) 山田忠史, 谷口栄一, 則武通彦, 堀江淳嗣 : 貨物共同 輸送の促進策に関する一考察, 土木計画学研究・論 文集, Vol. 16, pp. 717-724, 1999.

8) Ieda, H., Kimura, A. and Yi, Y. : Why don't multi-carrier joint delivery services in urban areas become popular? - A gaming simulation of carriers' behavior -, City Logistics II, pp. 155-167, 2001.

9) 谷口栄一, 山田忠史, 細川貴志: 都市内集配送トラッ クの配車配送計画の高度化・共同化による道路交通 への影響分析, 土木学会論文集, No. 625/IV-44, pp.
149-159, 1999.

10) van Duin, J. H. R. and Jagtman, E.: Best of both? Combining modelling insights of Japanese and Dutch practices, City Logistics I, pp. 117-131, 1999.

11) 山田忠史, 谷口栄一, 伊藤裕 : 貨物共同輸配送のモ デル化と効果および成立に関する一考察, 土木計画 学研究・論文集, Vol. 18, No. 3, pp. 409-416, 2001.

12) 山田忠史, 谷口栄一, 茂里一紘: 顧客分布と共同化 形態に着目した都市内共同配送の効果と成立に関す る分析, 土木計画学研究・論文集, Vol. 20, No. 3, pp. 657-663, 2003.

13) Nagurney, A., Dong, J. and Zhang, D.: A supply chain network equilibrium model, Transportation Research Part E, Vol. 38, pp. 281-303, 2002.

14) Yamada, T., Imai, K., Nakamura, T. and Taniguchi, E.: A supply chain-transport supernetwork equilibrium model with the behavior of freight carriers, Transportation Research Part E, Vol. 47, pp. 887-907, 2011.

15) Nagurney, A.: Network Economics: A Variational Inequality Approach, Kluwer Academic Publishers, Dordrecht, The Netherlands, 1999.

16) Kinderlehrer, D. and Stampacchia, G.: An Introduction to Variational Inequalities and their Application, Academic Press, New York, NY, 1980.

17) Meng, Q., Huang, Y. and Cheu, R. L.: A note on supply chain network equilibrium models, Transportation Research Part E, Vol. 43, pp. 60-71, 2007.

18) 山田忠史, 今井康治, 谷口栄一: 物流業者の行動を 考慮したサプライチェーンネットワーク均衡分析, 土木学会論文集 D, Vol. 65, No. 2, pp. 163-174, 2009.

19）ヤマト運輸：宅配便運賃一覧表, http://www.kuroneko yamato.co.jp/estimate/ichiran.html.（2016 年 2 月現在）

20) 山田忠史, 繁田健, 今井康治, 谷口栄一: 在庫費用 を考慮したサプライチェーンネットワーク均衡モデ ル：消費需要の不確実性に伴う物資流動量とネット ワーク効率性の変化, 土木学会論文集 D, Vol. 66, No. 3, pp. 359-368, 2010.

21) 国土交通省: 平成 26 年度宅配便等取扱実績について, http://www.mlit.go.jp/common/001097917.pdf（2016 年 2 月現在）

(2016. 2. 26 受付) 


\section{MODELLING AN URBAN COOPERATIVE DELIVERY SYSTEM WITH ITS \\ FARES AND VOLUMES ENDOGENOUSLY INCORPORATED TO INVESTIGATE THE KEY FACTORS FOR ITS SUCCESSFUL IMPLEMENTATION}

\section{Tadashi YAMADA and Kazuaki FUKUI}

The paper presents a freight transport network equilibrium model with an urban cooperative delivery system explicitly being incorporated. The model takes into account the decentralised decision-making of shippers, consumers, and freight carriers as well as their interaction. These are mathematically formulated, and the equilibrium conditions to be governed in the whole network are derived. Two types of freight carriers are involved in the system, a consigned one and a contracted one, where the former fully or partly consigns the urban goods delivery to the latter. The model endogenously determined the amount of goods transported/delivered, and the carriages incurred for the carrier-operated and cooperative transport/ delivery. Numerical examples are then undertaken, not only to validate the performance of the model, but to investigate the key factors for successfully implementing the cooperative system, focusing on the facility costs generated in delivery depots as well as on the vehicle operation costs incurred for the goods delivery in urban areas. 